\title{
Anaphylaxis Related to Passive Second-Hand Exposure to Cannabis sativa Cigarette Smoke in Adolescents
}

Cabrera-Freitag $\mathrm{P}^{1}$, Infante $\mathrm{S}^{1}$, Bartolomé $\mathrm{B}^{2}$, Álvarez-Perea $\mathrm{A}^{1}$, Fuentes-Aparicio $\mathrm{V}^{1}$, Zapatero Remón $\mathrm{L}^{1}$

${ }^{1}$ Pediatric Allergy Unit, Allergy Service, Hospital General Universitario Gregorio Marañón, Madrid, Spain

${ }^{2}$ Roxall, Departamento de I+D, Bilbao, Spain

J Investig Allergol Clin Immunol 2019; Vol. 29(4): 298-300 doi: $10.18176 /$ jiaci.0376

Key words: Cannabis sativa. Anaphylaxis. Adolescents. Passive secondhand exposure. Cannabis-fruit/vegetable syndrome.

Palabras clave: Cannabis sativa. Anafilaxia. Adolescentes. Inhalación indirecta. Síndrome cannabis-frutas/alimentos vegetales.

Cannabis sativa is an annual, dioecious, and anemophilous flowering plant that belongs to the Cannabaceae family. It contains more than 400 compounds, including more than 60 cannabinoids.

Although its recreational use is illegal in most countries, it is often consumed for its relaxing and euphoric effects.

The different preparations of $C$ sativa include marijuana, hashish, and hashish oil.

Different routes of exposure and sensitization to $C$ sativa have been described, as follows: (1) inhalation by smoking or vaporizing the drug, inhalation of C sativa pollen or exposure by proxy when allergens become airborne; (2) cutaneous contact through handling of $C$ sativa buds or indirect cutaneous contact; (3) chewing; (4) ingestion; and (5) intravenous use.

The clinical presentation of IgE-mediated allergy to $C$ sativa varies from mild to severe and often seems to depend on the route of exposure [1].

To date, severe IgE-mediated allergic reactions (anaphylaxis) have only been described in adults after ingestion of hempseed [2], drinking marijuana tea [3], and active marijuana smoking [4]

We report 2 cases of anaphylaxis in children after passive second-hand exposure to $C$ sativa cigarette smoke.

The first patient was a 14-year-old boy (Patient 1) with a previous history of anaphylaxis due to mustard seed ingestion and asthma caused by cypress pollen. He tolerated fruits (including peach), as well as nuts and wheat. His mother reported 2 episodes of generalized urticaria, difficulty breathing, and wheezing over a period of 3 months. In the first episode, he was skating on an open ice-skating rink where he reported smelling marijuana cigarette smoke; in the second episode, he was exposed to smoke from marijuana being consumed beside him at an open-air bus station. In neither of the 2 episodes was he carrying his epinephrine autoinjector and he treated the symptoms himself with inhaled salbutamol first and oral antihistamine at home. The symptoms resolved in less than an hour. 
The second patient was a 13-year-old girl (Patient 2) with a previous history of oral allergy syndrome with peach and allergic rhinoconjunctivitis induced by grass, olive, and plane tree pollen. The girl tolerated other fruits including apple and nuts. She reported an episode of generalized urticaria, facial swelling, difficulty breathing, wheezing, and dizziness while she was in a park where a group of people were smoking a marijuana cigarette close to her. She received emergency treatment with intramuscular epinephrine, intravenous dexchlorpheniramine, and methylprednisolone sodium succinate and was discharged from hospital after 6 hours of observation. Tryptase levels were not measured.

Neither of the children had previous direct contact with C sativa.

Protein extract from $C$ sativa buds (CSE) was prepared by homogenization in phosphate-buffered saline, dialyzation, and lyophilization. Both patients underwent skin prick testing (SPT) with CSE (10 mg/mL, Roxall), commercial peach lipid transfer protein (Pru p 3, ALK-Abelló), and palm pollen profilin (Pho d 10, ALK-Abelló).

Both patients had a positive SPT result to CSE (Patient 1, $4 \times 4 \mathrm{~mm}$; Patient 2, 10×8 mm) and Pru p 3 (Patient $1,9 \times 6 \mathrm{~mm}$; Patient $2,10 \times 8 \mathrm{~mm}$ ); Patient 1 also had a positive result to Pho d $10(10 \times 8 \mathrm{~mm})$. SPTs with CSE performed in 3 nonatopic individuals yielded negative results.

Serum specific IgE (sIgE, ImmunoCAP 250 [Thermo Fisher Scientific]) to Pru p 3 was positive in both patients (patient 1,>100 kU $\mathrm{A} / \mathrm{L}$; Patient 2, $44.2 \mathrm{kU}_{\mathrm{A}} / \mathrm{L}$ ), as well as to other nonspecific lipid transfer proteins (ns-LTPs) from plant foods (Patient 1, Tri a 14, 45.2 $\mathrm{kU}_{\mathrm{A}} / \mathrm{L}$; Cor a 8, $96.6 \mathrm{kU}_{\mathrm{A}} / \mathrm{L}$; Ara h 9, >100 kU $/ \mathrm{L}$; Patient 2, Mal d 3, $23.4 \mathrm{kU} / \mathrm{L}$; Cor a $8,5.34 \mathrm{kU}_{\mathrm{A}} / \mathrm{L}$; Ara h 9, $5.63 \mathrm{kU}_{\mathrm{A}} / \mathrm{L}$ ).
CSE was analyzed using SDS-PAGE under reducing conditions (2-mercaptoethanol) [5] and transferred onto polyvinylidene difluoride membrane filters. Incubation of sera from both patients revealed an IgE-binding band of approximately $10 \mathrm{kDa}$ in each case. A band with the same molecular mass was revealed with rabbit serum anti-Pru p 3 (Figure, A).

SDS-PAGE immunoblotting inhibition with CSE as solid phase and Pru p 3 as inhibitor was performed with both sera. The inhibition assay for Patient 1 showed partial inhibition of IgE binding, whereas that of Patient 2 showed total inhibition of IgE binding (Figure, B). An immunoblotting inhibition assay with Pru p 3 as solid phase and CSE as inhibitor was performed with serum from patient 1 , with total inhibition of IgE binding (Figure, C).

These results indicate that the ns-LTP from $C$ sativa (Can s 3) [6] is the trigger protein involved in the anaphylactic reaction experienced by both patients as a result of inhalation of $C$ sativa cigarette smoke. Furthermore, the results obtained with serum from patient 2 lead us to suppose that Pru p 3 was the primary sensitizing agent in this case and the $\operatorname{IgE}$ reaction with Can s 3 was a consequence of a cross-reaction event. However, the serum results for patient 1 (partial inhibition with Pru $\mathrm{p} 3$ as inhibitor, and total inhibition with CSE as inhibitor) informed us that Pru p 3 was not the primary sensitizing allergen in this case and that the primary sensitization allergen was probably Can s 3 itself or some other vegetable ns-LTP.

Although a marijuana cigarette smoke challenge test would have been the gold standard for diagnosis in these cases, it was not performed for obvious practical and ethical reasons, ie, both patients were under age and had previously had an anaphylactic reaction. The fact that both patients were
A

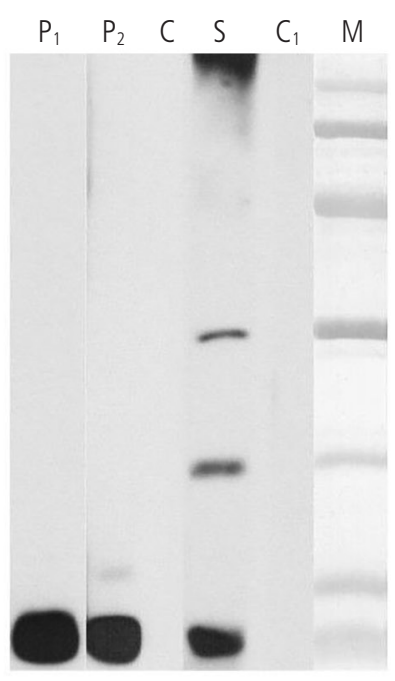

B

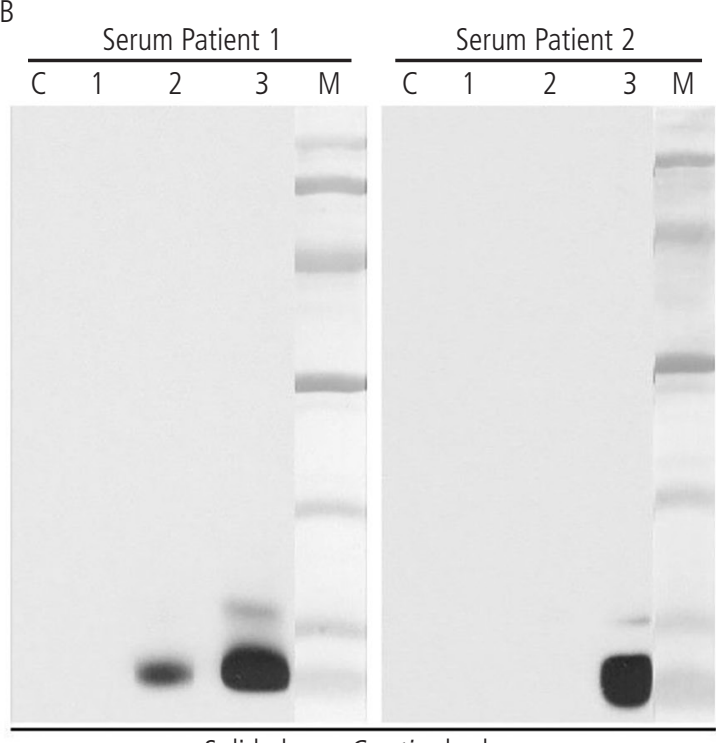

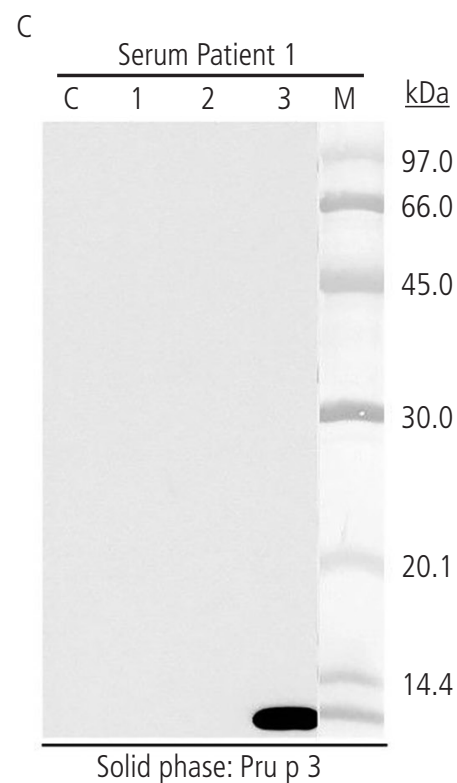

Figure. A, SDS-PAGE IgE-Immunoblotting with Cannabis sativa buds extract (CSE). Lane P1, serum from patient 1; Lane P2, serum from patient 2; Lane C, control serum (pool of sera from nonatopic individuals); Lane M, molecular mass standard; SDS-PAGE IgG-Immunoblotting. Lane S, rabbit serum anti-Pru p 3: Lane C1, rabbit serum before Pru p 3 immunization. B, Immunoblotting-inhibition with CSE as solid phase. Lanes 1-3, patient serum preincubated with CSE (1), with Pru p 3 (2), and with ovalbumin (3). C, Immunoblotting-inhibition with Pru p 3 as solid phase; Lanes 1-3, patient serum pre-incubated with Pru p 3 (1), with CSE (2), and with ovalbumin (3). 
adolescents could have led us to doubt that the reaction was produced by indirect inhalation of marijuana cigarette smoke and not by direct inhalation. However, in the case of Patient 2, the reaction occurred in the presence of relatives; Patient 1 was a professional soccer player who underwent antidoping drug testing on a regular basis, with negative results.

As mentioned above, anaphylaxis related to $C$ sativa consumption in different preparations has been reported, but not in relation to passive smoking. To our knowledge, these are the first 2 cases of anaphylaxis in children induced by passive second-hand exposure to $C$ sativa cigarette smoke. The ns-LTP Can s 3, which is involved in the cannabis-fruit/ vegetable syndrome [7], could be the allergen responsible for this severe reaction.

\section{Funding}

The authors declare that no funding was received for the present study.

\section{Conflicts of Interest}

The authors declare that they have no conflict of interest.

\section{References}

1. Decuyper II, Van Gasse AL, Cop N, Sabato V, Faber MA, Mertens $C$, et al. Cannabis sativa allergy: loooking through the fog. Allergy. 2017;72:201-6

2. Stadtmauer G, Beyer K, Bardina L, Sicherer SH. Anaphylaxis to ingestion of hempseed (Cannabis sativa). J Allergy Clin Immunol. 2003;112:216-7.

3. Tessmer A, Berlin N, Sussman G, Leader N, Chung EC, Beezhold D. Hypersensitivity reactions to marijuana. Ann Allergy Asthma Immunol. 2012;108:282-4.

4. Faber M, Van Gasse A, Sabato V, Hagendorens MM, Bridts $\mathrm{CH}$, De Clerck LS et al. Marihuana allergy: beyond the joint. J Investig Allergol Clin Immunol 2015;25:70-2.

5. Laemmli UK. Cleavage of structural proteins during the assembly of the head of bacteriophage T4. Nature. 1970;227:680-5.

6. Gamboa P, Sanchez-Monge R, Sanz ML, Palacin A, Salcedo G, Diaz-Perales A. Sensitization to Cannabis sativa caused by a novel allergenic lipid transfer protein, Can s 3. J Allergy Clin Immunol. 2007; 12:1459-60.

7. Ebo DG, Swerts $S$, Sabato $V$, Hagendorens MM, Bridts $\mathrm{CH}_{\text {, }}$ Jorens PG et al. New food allergies in a European nonMediterranean region: is Cannabis sativa to blame? Int Arch Allergy Immunol. 2013;161:220-8.

Manuscript received November 23, 2018; accepted for publication January 14, 2019.

Paula Karin Cabrera Freitag

Departamento de Alergia

Hospital Gregorio Marañón

Calle Dr. Esquerdo

Madrid, Spain

E-mail: paula.cabrera@salud.madrid.org 